\title{
Application of microscale combustion calorimeter to characterize protective properties of bovine leather
}

\author{
Franka Žuvela Bošnjak1, Sandra Flinčec Grgac ${ }^{1}$, Suzana Mihanović ${ }^{1}$ \\ 1 Sveučilište u Zagrebu Tekstilno-tehnološki fakultet, Prilaz baruna \\ Filipovića 28a, 10000 Zagreb, Hrvatska \\ Psunj d.o.o., Kožarska 18, Rešetari, Hrvatska \\ franka.zuvela.bosnjak@ttf.hr, sflincec@ttf.hr, production@viviani.hr
}

Original Scientific Paper

DOI: $10.34187 / k o .68 .4 .2$

\begin{abstract}
:
The quality and properties of fire resistance are crucial to the selection of leather for the production of protective fire fighting boots, which has a primarily protective role. During fire extinguishing it is exposed to extremely high and low temperatures, chemicals (acids and alkalis), mechanical loads, etc. The properties of fire resistance were tested on two samples of bovine leather (BL1, BL2). Burn resistance test has been carried out in accordance with the requirements of the technical standards for the burn resistance test: HRN EN ISO 15090: 2012 - Footwear and firefighters. The mentioned two samples were individually tested according to HRN EN ISO 15025: 20016 - Protective clothing - Flame protection - Method limited flame spread tests. The test procedure was carried out by the "Flame Expansion Testing Method". Moreover, in this research used Microscale Combustion Calorimeter (MCC) Govmark, UK because that was designed for produce the maximum heating rate capability similarly the heating rates in fires and give as a lot of flammability parameters. The analysis of physicochemical properties of samples was performed using Fourier transform infrared (FTIR) spectroscopy. The surface morphology of the samples was studied using a Field Emission Scanning Electron Microscopy (FE-SEM). The measurement of the above samples on MCC was performed according to ASTM D7309. The natural characteristics of the grain side are not visible on the samples. Observed (shown) irregularities of the VK2 sample are attributed to an artificial face of the leather. From the obtained HRR results, it is evident that BL1 sample has a better thermal stability than the BL2 sample.
\end{abstract}

\section{Keywords:}

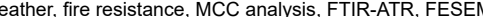 \\ 1. Introduction}

The occupational hazards that are presented in protection industry pose a number potential risk for injuries. Wearing personal protective equipment is the only, irreplaceable protection for profession who are exposed to multiple hazards. Fire fighting boots are important part of special protective equipment. They protect firefighters not only from flame and high heat, but also from exposure to hazardous liquid, physical, and electrical hazards [1] Leather goods have played a major role in protecting the human body from external influences from the existence of human race. Skins have to be treated with many processes including soaking, degreasing, unhairing, liming, picking, tanning, retanning, fatliquoring and finishing to achieve finished and utility leather. During these processes, many different materials were added in the leather tissue and therefore would influence the flammability of leather. Among those treatments, tanning is one of the most important factors that affect fire retardance of leather [2]. The most important feature of leather is its fibrous structure. Leather is characterised by a high permeability for water vapour and other gases and, at the same time, very low water permeability. The characteristic structure of leather can explain many properties of tanned leather such as tear resistance, flexibility, permeability for air, thermal insulation, resistance to water and shape maintenance [3]. However, leather is a natural material considered a very high-tech product that is progressively being used to a larger extent in different sectors: automotive, domestic upholstery, buildings, aviation, maritime, personal safety, etc. [4]. Bovine leather has generally firm and tight collagen tissue, especially in the back parts. In this type of leather, the papillary layer is loosely constructed and is relatively small compared to the reticular layer. Bovine leather of such structure is used for the production of leather, which have high resistance to mechanical stresses [5]. Faire resistant boots are made mostly of the bovine box. Leather box, tanned with chrome or in combination with chrome and other types of tanning agents, are used for making tops of footwear and other products. They are made mostly with a smooth, natural face and broken or embossed face. The main characteristics of leather box are: fullness, flexibility, softness, good strength, elasticity and thick texture of leather tissue. These properties are connected with fibrous structure of leather tissue constructed of collagen fibers, depending on the type and quality of the raw material and on the performed technological processing operations [5]. Parts of leather from back of the animal is most commonly used for footwear parts that are exposed to the greatest mechanical and thermal influences. The reason for these properties is fibrous structure of the finished leather, which consists of nettle fibers and fibrils. The more vertical fibers make leather tissue more firm and thicker. The back of the leather abounds with collagen and this part of the leather tissue is the strongest and the most densely which provides good mechanical and thermal properties to the objects made by it [6]. Flame resistant fabrics for industrial and military uses represent one of a few most profitable niche markets in the global textile complex. Most of the textile materials, are flammable, therefore applying flame retardants to textile fabrics becomes necessary to assure human safety under many circumstances [7]. Leather is more fire resistant than textile but every type of leather don't have good flame resistance. It depend on type of leather, type of processing and also final finishing of leather. In this research, burn resistance test carried out by the "Flame Expansion Testing Method" and Microscale Combustion Calorimeter (MCC) has been applied, for determining the flammability of two different leather samples used for fire fighting boots to get flammability parameters for assessment usability leather.

\section{Materials and methods}

\subsection{Materials}

Two samples of bovine leather were subjected to heat stability and burn (flame) resistance testing. First sample is fireproof bovine box (BL1), 2.3$2.5 \mathrm{~mm}$ thick, most commonly used for upper part of firefighting boots. Second sample is perforated bovine leather (BL2) with corrected grain and polyurethane finish are most commonly used for collar of fire fighters' boots. Both leather samples are dyed in black.

\subsection{Burn resistance test}

Test conducted in accordance with HRN EN ISO 15025: 2003.[9]. The samples were subjected to a standard atmospheric temperature of $23^{\circ} \mathrm{C}( \pm$ $\left.2{ }^{\circ} \mathrm{C}\right)$ and a relative humidity of $50 \%( \pm 5 \%)$ prior to testing.

\subsection{FT-IR spectroscopy}

The analysis of physicochemical properties of samples was performed using attenuated total reflectance (ATR) Fourier transform infrared (FT-IR) spectroscopy (Perkin Elmer, software Spectrum 100). Four scans were done for each sample, at the resolution of $4 \mathrm{~cm}^{-1}$ between $4000 \mathrm{~cm}^{-1}$ and $380 \mathrm{~cm}^{-1}$.

\subsection{MCC measurement}


The MCC measurement was performed using an "MCC-2" micro-scale combustion calorimeter produced by Govmark, Farmingdale, New York, according to ASTM D7309-2007 (Method A). To improve sample uniformity, the leather were first ground in a Wiley mill to form homogeneous powders The sample thus prepared (fiber powder), approximately $5 \mathrm{mg}$, was heated to a specified temperature using a linear heating rate of $1{ }^{\circ} \mathrm{C} / \mathrm{s}$ in a stream of nitrogen flowing at $80 \mathrm{~cm}^{3} / \mathrm{min}$ flow rate. The thermal degradation products (fuel gases) were mixed with a $20 \mathrm{~cm}^{3} / \mathrm{min}$ stream of oxygen prior to entering a $900{ }^{\circ} \mathrm{C}$ combustion furnace. Each sample was run in three replicates and the data presented here are the averages of the three measurements. The combustion of fuel gases in the mixture of $20 \% \mathrm{O}_{2}$ and $80 \% \mathrm{~N}_{2}$ at $900{ }^{\circ} \mathrm{C}$ for $10 \mathrm{~s}$ is a very conservative condition to ensure complete oxidation of the fuel gas [8]. All curves presented in this paper show no saturation of HRR, confirming the complete oxidation of the fuel gases. In this research, the MCC experiments are performed according to "Method A" of ASTM 7309, which specifies that the degradation of samples takes place in nitrogen atmosphere [7]

\subsection{Scanning Electron Microscopy (SEM)}

Besides the physical-chemicals characterization of samples, the leather surface morphology of the grain surface and flesh side surface was observed with MIRA, LMU Tescan, field emission scanning electron microscope (FE-SEM). The samples were mounted on stubs and coated for $240 \mathrm{~s}$ with chromium in a sputter coater Quorum-Q150T ES.

\section{Results and discussion}

\subsection{Results of fire resistance test}

After fire extinguishing, none of the samples continued to burn. Finished fireproof leather of the BL1 bovine box was not damaged and is the ideal material for the firefighter's upper parts of footwear. BL2, the perforated bovine fireproof leather with the artificial face is partially coated and shrunken in the centre, where it was exposed to flame.

\subsection{FT-IR spectroscopy measurement}

To determine protein structure and dynamics of structure infrared spectral band frequency, band intensity, and band width can be used. Using infrared spectroscopy for protein structure analysis the vibration of the protein amide bonds are the concrete indicators [10]. FT-IR analysis of leather samples implies infrared radiation to assess vibrational modes particular for protein molecules and relating this to the primary, secondary, tertiary, and quaternary structure of the protein. Two main bands of the collagen are Amide I and Amide II bands. The Amide I band ( 1650 $\left.\mathrm{cm}^{-1}\right),(70-85 \%)$ is determined by the backbone conformationand the hydrogen bonding pattern and it is mainly associated with the $\mathrm{C}=\mathrm{O}$ stretching vibration. Amide II $\left(\sim 1550 \mathrm{~cm}^{-1}\right)$ results from the $\mathrm{N}-\mathrm{H}$ bending vibration and from the $\mathrm{C}-\mathrm{N}$ stretching vibration. Amide III $\left(\sim 1235 \mathrm{~cm}^{-1}\right)$ depending on hydrogen bonding and on side chains of collagen structure [11]. Results also point characteristic pikes for polyurethane. $2927-2854 \mathrm{~cm}^{-1}$ corresponds to the methylene group (-CH2-). Between $1705-1691 \mathrm{~cm}^{-1}$ the hard segments carbonyl bands can be observed. The $\mathrm{C}-\mathrm{N}$ stretching bands, combined with those of the bending of $\mathrm{N}-\mathrm{H}$, are typically observed at $1523 \mathrm{~cm}^{-1}$ and 1446 $\mathrm{cm}^{-1}$, demonstrating the occurrence of the reaction between the hydroxyl group and the isocyanate [11]. These results confirm that both leather samples contain in their structure both grain and flesh sides polyurethane compound.

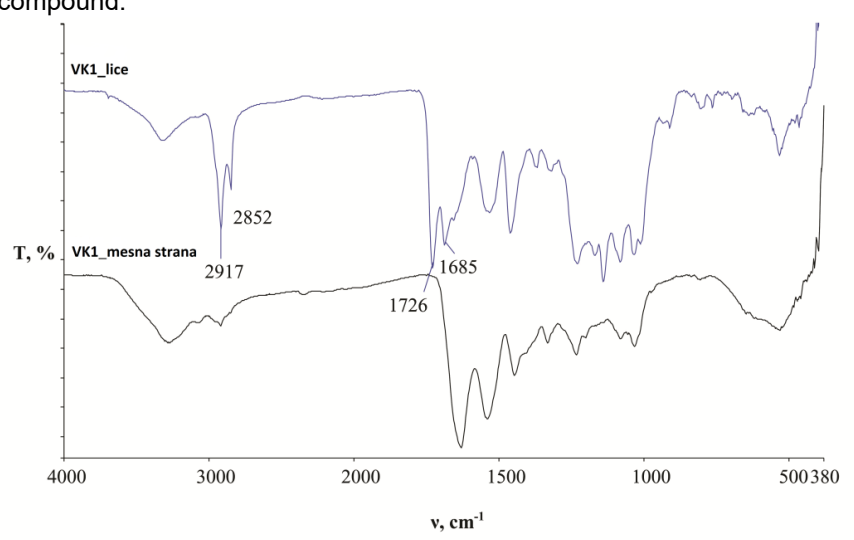

Figure 1: spectrum curves of BL1

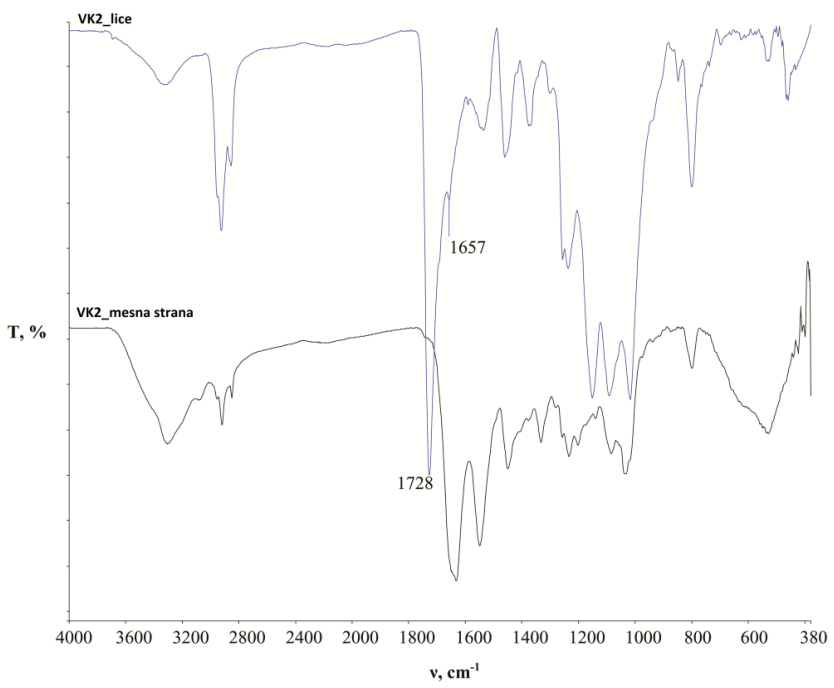

Figure 2: spectrum curves of BL2

\subsection{Results of MCC measurement}

Table 1 shows the values that are extremely important for the characterization of samples intended for firefighting footwear with respect to the heat and flame resistance obtained by analysis at the MCC.

\begin{tabular}{|c|c|c|c|c|c|c|}
\hline Table 1: Results of & 1céahals & $s$ of & $3 \mathrm{~L} 1$ and $\mathrm{B}$ & 2 sample & & \\
\hline & $\bar{X}$ & $S$ & CV \% & $\bar{X}$ & $S$ & CV \% \\
\hline $\begin{array}{c}\text { Heat release } \\
\text { capacity, } \eta \mathrm{c}, \mathrm{Jg}^{-1} \mathrm{~K}^{-1}\end{array}$ & 82,00 & 1,73 & 0,021123 & 85,00 & 1,00 & 0,011765 \\
\hline $\begin{array}{l}\text { Maximum specific } \\
\text { heat release, } \\
\text { Qmax. } \mathrm{Wg}^{-1}\end{array}$ & 81,39 & 1,25 & 0,015302 & 86,00 & 1,14 & 0,013295 \\
\hline $\begin{array}{l}\text { Heat release } \\
\text { temperature, Tmax, } \\
{ }^{\circ} \mathrm{C}\end{array}$ & 400,60 & 0,98 & 0,002459 & 379,10 & 2,77 & 0,007315 \\
\hline $\begin{array}{l}\text { Specific heat } \\
\text { release, hc, } \mathrm{kJg}^{-1}\end{array}$ & 8,53 & 0,45 & 0,052843 & 10,40 & 0,61 & 0,058488 \\
\hline $\begin{array}{l}\text { Yield of pyrolysis } \\
\text { residue, Yp, } \mathrm{gg}^{-1}\end{array}$ & 1,27 & 0,18 & 0,141732 & 1,17 & 0,05 & 0,038651 \\
\hline $\begin{array}{c}\text { Average release } \\
\text { capacity, } \mathrm{\eta c}, \mathrm{Jg}^{-1} \mathrm{~K}^{-1}\end{array}$ & 93,67 & 3,79 & 0,040419 & 92,00 & 0,00 & 0 \\
\hline $\begin{array}{c}\text { Average release } \\
\text { temperature Tmax, } \\
{ }^{\circ} \mathrm{C}\end{array}$ & 349,27 & 0,55 & 0,001577 & 347,27 & 0,85 & 0,002449 \\
\hline
\end{tabular}

In order to characterize as accurately as possible, the leather samples BL1 and BL2 with respect to the behaviour under the action of heat were subjected to analysis on an MCC device. From Table 1 we can see that sample BL1 has a mean maximum specific heat released $\left(81.39 \mathrm{Wg}^{-1}\right)$ lower than sample BL2 $\left(86 \mathrm{Wg}^{-1}\right)$. An indicator of the thermal stability of the samples is the amount of charred residue after analysis, and it can be seen that the sample BL1 $\left(1,27 \mathrm{gg}^{-1}\right)$ has a slightly larger residue compared to the sample BL2 $\left(1,17 \mathrm{gg}^{-1}\right)$. From all the above, it can be concluded that the BL1 sample shows slightly better heat resistance results. However, both samples show good thermal stability results.

\subsection{Results of Scanning Electron Microscopy (SEM)}

The morphological characterization of the surface was analysed by FESEM in order to try to identify the difference of the structures between BL1 and BL2 samples on grain side and flesh side. Figure 3: $a$ ) and b) show the grain side surface of sample BL1 with magnifications $1000 \mathrm{x}$ and $5000 \mathrm{x}$. It can be seen polyurethane adhesive applied to the natural face of the leather, which covers the natural face characteristics. Figure 4: a) and b) shows the grain side surface of sample BL2. The face of this sample is artificial, polyurethane finish applied on splited leather. The finish layer on grain side of BL2 is more uneven and irregular, which can be attributed to the characteristics of the application itself, i.e. the finish. The larger layer of 


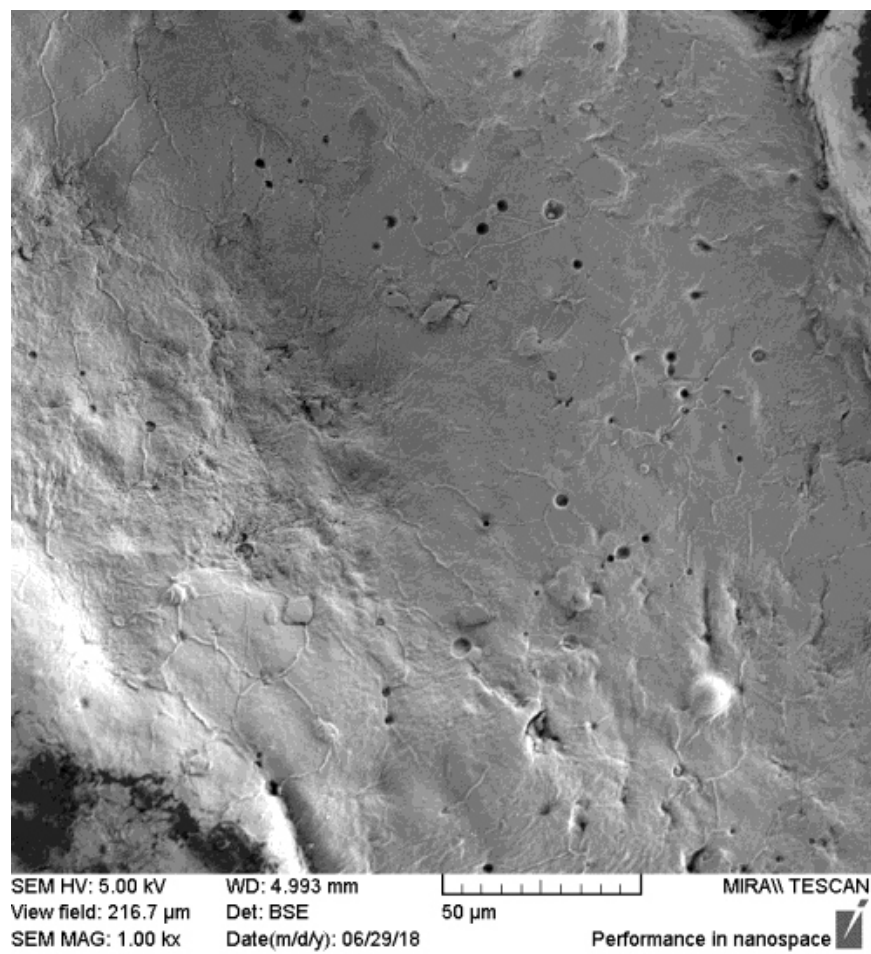

a

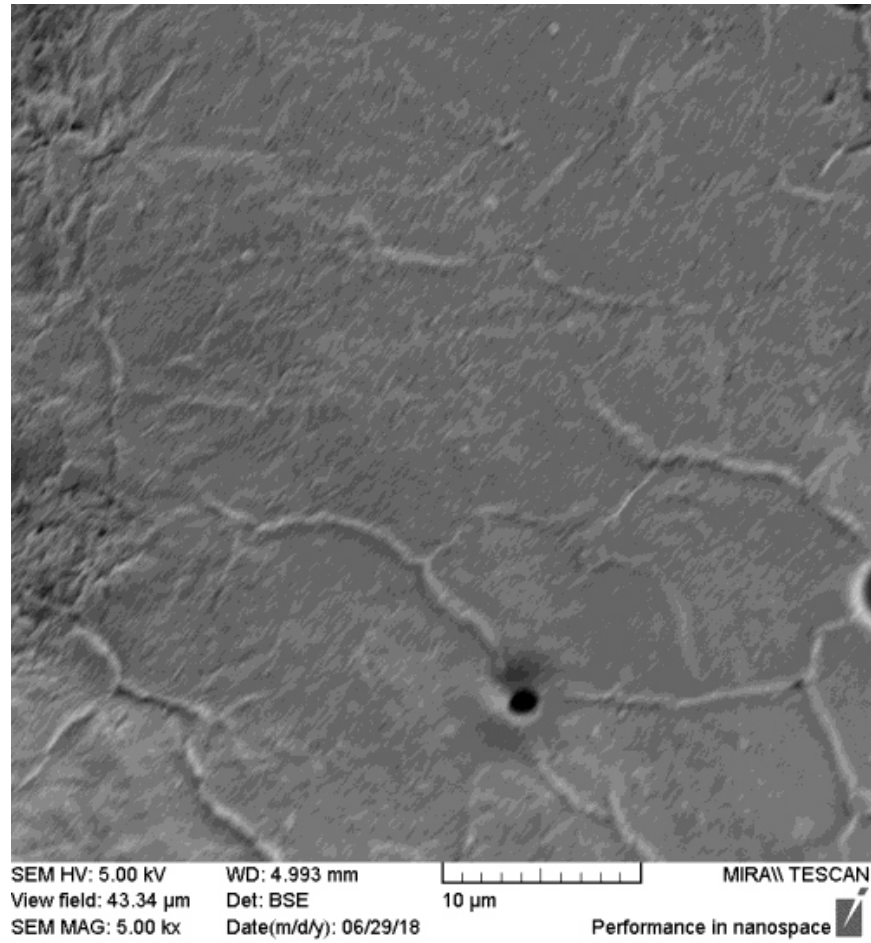

b

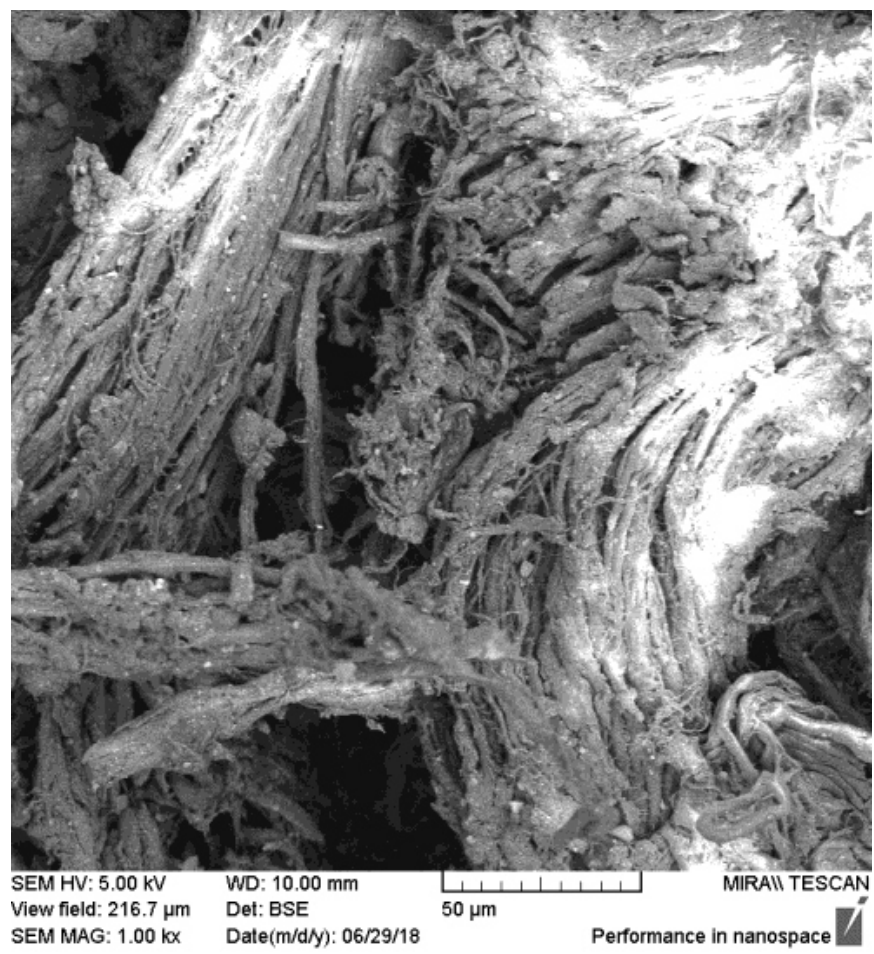

C

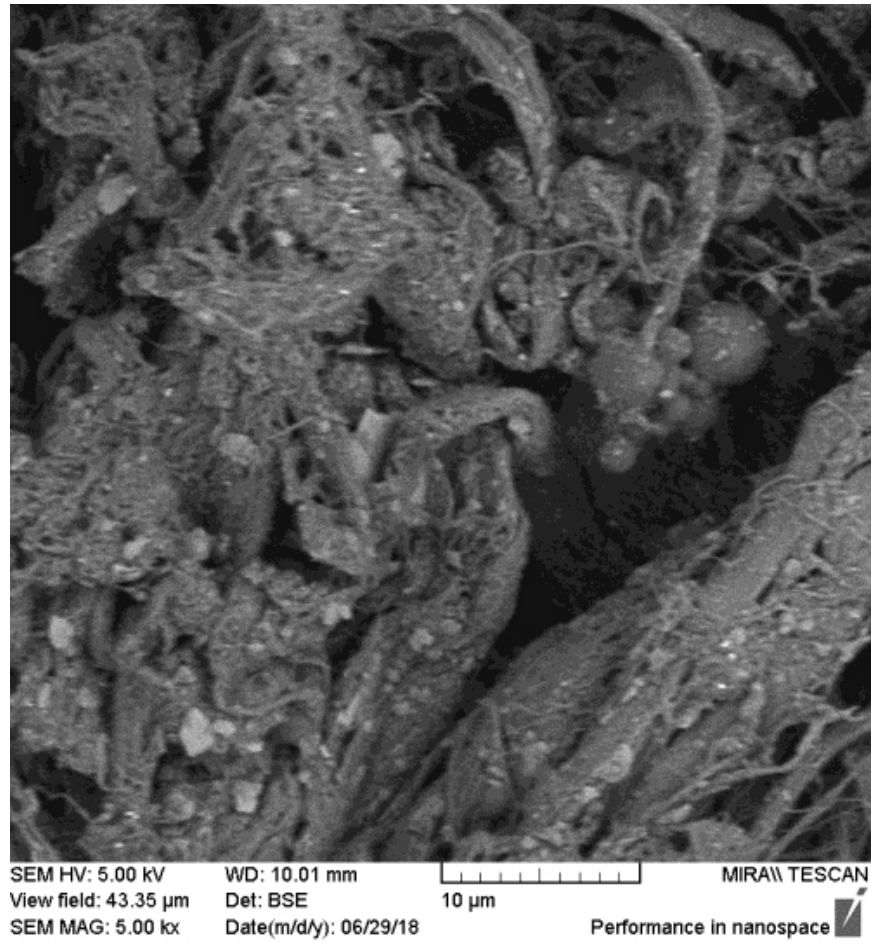

$\mathrm{d}$

Figure 3: Morphology of the grain surface $(a, b)$ and flesh sid surface $(c, d)$ sample BL1 at different magnifications: $a, c-1000 x ; b, d-5000 x$

finish gives a more closed face structure and visible irregularities. Figure 3 : c) and d) show the flash side of sample BL1 while figure 4: c) and d) shows the flesh side of sample BL2. Comparing these sides of two samples it can be concluded that BL1 sample is more compact. The flesh side of the BL2 sample is brushed, so the fibre bundles are evenly oriented and without tangled dirt.

\section{Conclusion}

Infrared spectroscopy confirm Amide I, Amide II, and Amide III bonding's which are normally present in collagen structure. Results also show polyurethane compounds in both samples, on grain and flesh side which confirm that both samples have polyurethane finish in their structure. MCC results for BL1 sample show slightly better heat resistance but it can be concluded that both samples have good thermal stability. The morphological characterization of the surface analysed by FE-SEM showed a visible difference between the grain sides of the samples. Natural face characteristics are not visible on any of the sample. BL2 has an artificial face, so it shows a more closed structure and more irregularities caused by

artificial layers on split leather. Sample BL2 have cleaner grain side without dirt than BL1. Sample BL1 shows greater stability to the action of open flames and as such is much more suitable for the manufacture of fire fighter boots. Sample BL2 is used only for collar of fire fighters boots not for whole boots.

\section{Acknowledgments}

The research is conducted from support for research 2020. Finishing and maintenance of textiles and leather with environmentally friendly agents, Assist. Prof. Tihana Dekanić.

The paper was published on XIII. International Scientific-Professional Textile Science and Economy, Zagreb, Croatia 

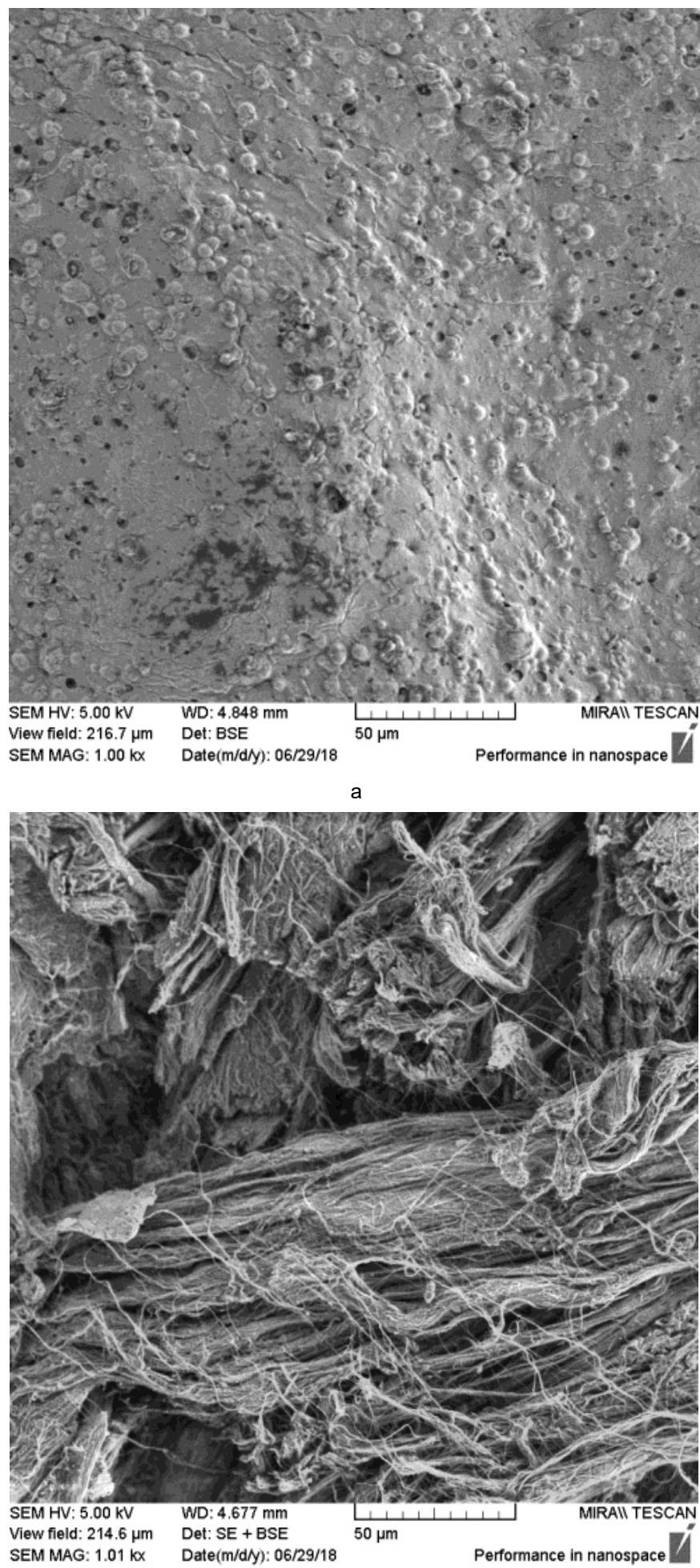

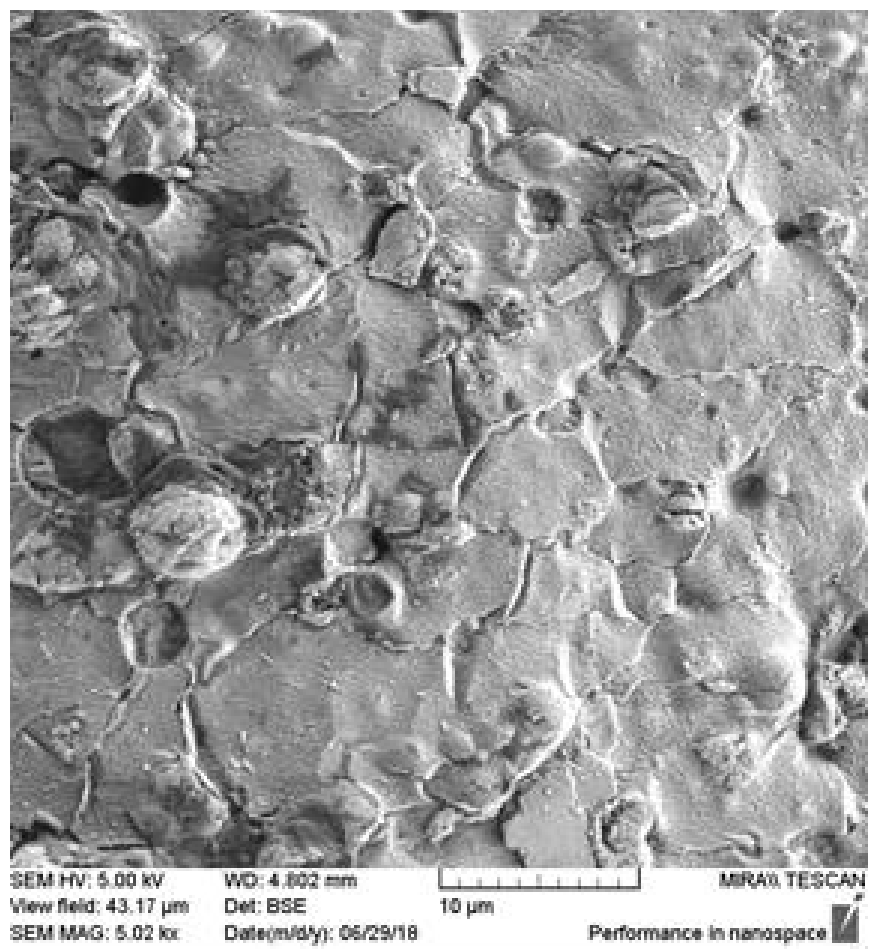

C

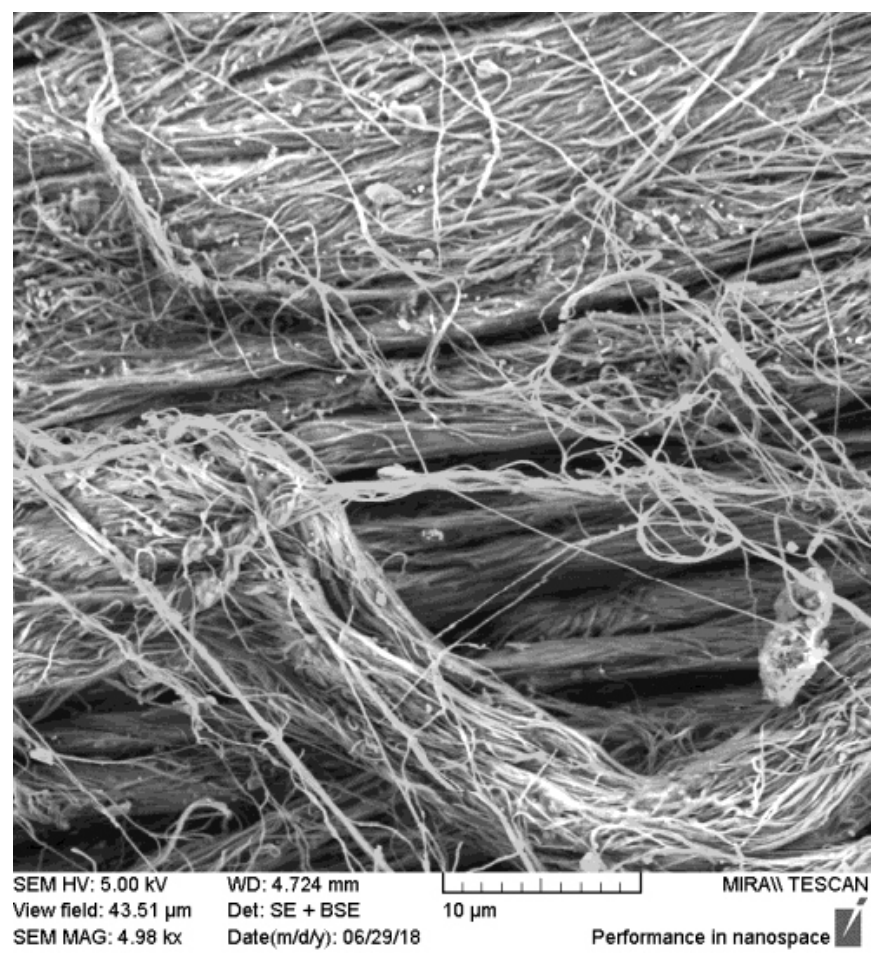

d

Figure 4: Morphology of the grain surface $(a, b)$ and flesh side surface $(c, d)$ sample BL2 at different magnifications: $a, c-1000 x ; b, d-5000 x$

\section{REFERENCES}

[1] Irzmańska, E.: The microclimate in protective fire fighter footwear: Foot temperature and air temperature and relative humidity, Autex Research Jurnal, 16 (2016) 2, pp. 75-79, ISSN: 2300-0929

[2] Fan, C.; et al: Influence of retanning materials with different properties on the flammability of leather, Leather and Footwear Journal, 13 (2013) 3 , pp. 179-186, ISSN: 1583-4433

[3] http://www.leathermag.com/features/featureflammability-andflameretardancy-of-leather/, Accessed: 2020-02-28

[4] Bacardit, A,; Behavior of Leather as a Protective Heat Barrier and Fire Resistant Material, Journal- American Leather Chemists Association, 105 (2010), pp. 51-61, ISSN: 00029726

[5] Grgurić, H.; Vuković, T.; Bajza, Ž.: Tehnologija kože i krzna, Zajednica kem., kožarskih, obućarskih, gum. i rud. organizacija, Zagreb, (1985)

[6] Radanović, Z.: Poznavanje kožarskih materijala i njihovo ispitivanje,
Zagreb, (1989)

[7] Q. Yang, C. et al; Investigation of the flammability of different textile fabrics using micro-scale combustion calorimetry, Polymer Degradation and Stability, 95 (2010), pp. 108-115, ISSN: 01413910

[8] Lyon, R.; Walters, R.; Stoliarov, S.; Thermal analysis of flammability, Journal of Thermal Analysis and Calorimetry, 89 (2007) 2, pp. 441-448, ISSN: 15882926, 13886150

[9] HRN EN ISO 15025:2003. Zaštitna odjeća - Zaštita od topline i plamena - Metoda ispitivanja za ograničeno širenje plamena [10] Sendrea, C. et al; Non-invasive characterisation of collagen based on materials by NMR-MOUSE and ATR-RTIR, UPB Scientific Bulletin, Series

B: Chemistry and Materials Scienceopen access, 78 (2016), pp. 27-38, ISSN: 14542331

[11] S.Gregorí Valdés, B. et al; New Biocompatible Polyurethanes: Synthesis, Structural Characterization and Cytotoxicity, (2018) 2018090445, doi:10.20944preprints201809.0445.v1 